\title{
RESEARCH ON SUBSURFACE DRIP IRRIGATION OF GRAIN SORGHUM IN SANDY SOILS
}

\section{Dragos Manea ${ }^{1}$, Iulian Draghici ${ }^{2}$, Reta Draghici ${ }^{2}$, Mihai Gidea ${ }^{3}$}

${ }^{1}$ National Institute of Research-Development for Machines and Installations Designed to Agriculture and Food Industry, Romania; ${ }^{2}$ Research And Development Station For Plant Culture On Sandy Soils

Dabuleni, Romania; ${ }^{3}$ University of Agronomic Sciences and Veterinary

Medicine of Bucharest, Romania

manea_dragos_05@yahoo.com, iuliandraghici54@yahoo.com, retadraghici@yahoo.com, gideam@yahoo.com

\begin{abstract}
The paper presents the results of the subsurface irrigation experimental research at grain sorghum. The experiment was located on a sandy soil plot, in the arid Dăbuleni region of southern Romania, under the climatic condition of 2020. Two variants of subsurface drip irrigation were placed: at a depth of $20 \mathrm{~cm}$ and at a depth of $40 \mathrm{~cm}$. Observations and determinations were made regarding the soil humidity on the profile of 0-20 cm, 20-40 $\mathrm{cm}$ and 40-60 $\mathrm{cm}$. Hydro physical indices (momentary water supply, the soil water reserve and the soil water deficit) were calculated to establish the irrigation norms according to the water consumption of the grain sorghum. The analysis of the results obtained for sorghum cultivation highlighted better use of subsurface irrigation with the location of drip lines at $40 \mathrm{~cm}$ depth, the level of grain production being $5758.3 \mathrm{~kg} \cdot \mathrm{ha}^{-1}$, with a difference of $1182.3 \mathrm{~kg} \cdot \mathrm{ha}^{-1}$, distinctly significant from the irrigation located at $20 \mathrm{~cm}$ depth. Using this method, the water is distributed in the area of root development and ensures optimal humidity in the soil for a longer period, with no losses, compared to the burial variant of the drip lines at $20 \mathrm{~cm}$, when a significant part of the water that rises in the soil layer to the surface, through the capillary ascent, is lost by evaporation.
\end{abstract}

Keywords: subsurface irrigation, sandy soil, grain sorghum.

\section{Introduction}

Efficient use of water by modern irrigation systems is becoming increasingly important in arid and semi-arid regions with limited water resources. In order to establish the water consumption, the irrigation regime and the moment of watering, many factors must be taken into account regarding the relationships and interrelationships between the soil, plant and water in certain given environmental conditions, crop structure, etc. [1].

Subsurface drip irrigation is a micro-irrigation system that could be adopted by producers in semiarid regions around the world for efficient water use. However, the impact of the burial depth of drip lines plays the key role in crop management. Thus, a study conducted in the southern Great Plain of the USA [2] highlights the location of the drip line at a depth of $30 \mathrm{~cm}$ and at a distance of $153 \mathrm{~cm}$ between two lines, the rows of plants being sown at a distance of $76 \mathrm{~cm}$.

The development of sorghum crops is influenced by the soil type [3], hybrid type [4], cultivation technology [5], and last but not the least, by water deficit in the field [6]. Research on sorghum cultivation has shown better efficiency of subsurface drip irrigation compared to sprinkler irrigation [79]. A study in central Greece, concluded that the method of subsurface drip irrigation was superior to the surface irrigation, in terms of quantitative and qualitative characteristics of growth, productivity, energy production of sorghum fibres [10]. This superiority is mainly due to the reduction of losses due to decreased evaporation, as well as the more efficient distribution of water and nutrients in the root zone. The fully automatic subsurface irrigation system placed at a depth of $45 \mathrm{~cm}$ from the soil surface positively influenced the development of sorghum plants (plant height, leaf surface index), as well as the production obtained per unit area [11].

Because sorghum is a drought-tolerant crop, it is often preferred by growers in cases of expected water stress. Thus, grain sorghum tolerates and avoids drought more than other cereals, but in conditions of prolonged drought, sorghum reacts with significant production losses. Water stress in the vegetative growth stage can reduce production by more than $36 \%$, and water stress in the reproductive stage (panicbean formation phase) can reduce production by more than 55\% [12]. In terms of humidity, sorghum is less demanding than of heat. When water is insufficient, sorghum plants sharply reduce their growth rate, which is resumed with a specific intensity when the humidity becomes favourable. The analyses of thermal and water resources have highlighted a trend of increasing drought in the last two decades, with unfavourable effects on agriculture in southern Romania [13]. 
This paper presents the results of the subsurface irrigation experimental research in grain sorghum. The experiment was located on a sandy soil plot, in the arid region Dăbuleni of southern Romania (N: $\left.43^{\circ} 48^{\prime}, \mathrm{E}: 24^{\circ} 5^{\prime}\right)$, under the climatic condition of 2020.

\section{Materials and methods}

The sandy soils from southern Romania are coarse-textured soils, containing less than $12 \%$ colloidal clay and low humus (0.1-1.6\%). Sandy soils have a low natural fertility, being poorly supplied with nitrogen and phosphorus and medium supplied with potassium. From a climatic point of view, the sandy soil area has a pronounced continental character with a slight Mediterranean influence, which is manifested by an accentuated drought in July-September and a normal amount of precipitation in May and June. The average annual temperature is $11.1^{\circ} \mathrm{C}$. The multiannual average rainfall is $548 \mathrm{~mm}$, being unevenly distributed in months and with large variations from one year to another.

Description of the experimental plot. The subsurface irrigation installation was implemented in an experimental plot with an area of $500 \mathrm{~m}^{2}$ (50 m long and $10 \mathrm{~m}$ wide) (Figure 1). Subsequently, a grain sorghum crop was established on this surface. The drip lines were placed in the soil at two depths, $20 \mathrm{~cm}$ and $40 \mathrm{~cm}$, with the help of specialized technical equipment. The distance between two adjacent drip lines was $1 \mathrm{~m}$.

The drip tubes used are intended for subsurface irrigation, with drippers with compensated pressure and anti-siphon, the distance between the drippers being $33 \mathrm{~cm}$, and the outer diameter of the tube 16 $\mathrm{mm}$. The subsurface irrigation system was supplied with water from an above-ground irrigation canal, with the help of a Lorentz pump supplied with electricity from a hybrid, solar and wind source.

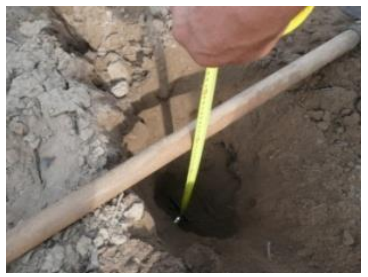

subsurface irrigation

lines buried in the ground

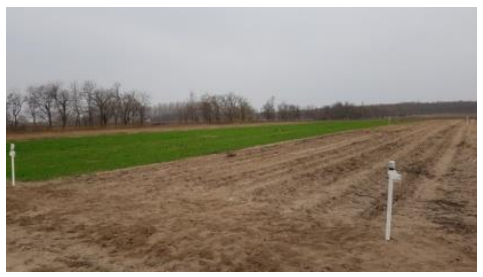

experimental plot at the end of the subsurface irrigation installation

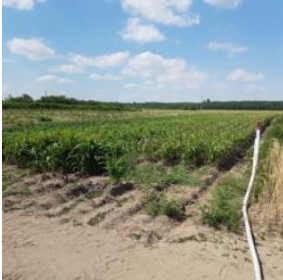

grain sorghum crop, July 15

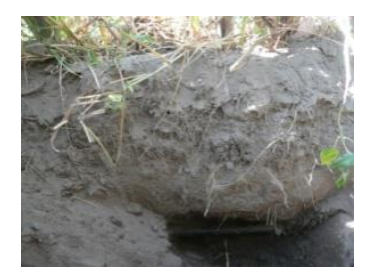

sorghum root area

Fig. 1. Outline of the experimental plot

Description of the experimental method. The experiment was organized according to the method of plots subdivided with two factors, namely:

- Factor A: irrigation method (a1- subsurface irrigation located at a depth of $20 \mathrm{~cm}$ and $\mathrm{a}_{2}-$ subsurface irrigation located at a depth of $40 \mathrm{~cm}$ );

- Factor B: depth of the sampling soil humidity $\left(b_{1}=0-20 \mathrm{~cm} ; b_{2}=20-40 \mathrm{~cm} ; b_{3}=40-60 \mathrm{~cm}\right)$.

In the experiments, the soil humidity was determined in dynamics with the help of the ThetaKit device, on the depth intervals of $0-20 \mathrm{~cm}, 20-40 \mathrm{~cm}$ and $40-60 \mathrm{~cm}$. The following hydro physical soil indices were calculated to establish the irrigation norms, according to the water consumption of the grain sorghum crop: the momentary water supply, the soil water reserve and the soil water deficit [14].

Determinations of biometrics of the sorghum plant were performed: plant size, stem diameter, panicle length, leaf area index, hectolitre mass, mass of one thousand grains. From a physiological point of view, the behaviour of the sorghum plant grains at the thermohydric stress in the phenophase of flowering-bean formation was followed, the processes of photosynthesis, perspiration, stomatal conductance (with LC Pro SD device), chlorophyll content (with CCM device 200 Plus) being determined, as well as the content of leaves in water and dry matter (with the gravimetric method).

The results obtained were calculated and statistically analyzed by the analysis of variance (ANOVA).

\section{Results and discussion}

Evolution in dynamics of soil humidity (Table 1). In the bellows phenophase of sorghum plants (early July) it can be seen that in the variant, in which the irrigation is located at the depth of $20 \mathrm{~cm}$, the 
soil humidity has evolved upwards from $9.1 \%$ at the depth of $20 \mathrm{~cm}$ to $10.3 \%$ on the soil profile 40 $60 \mathrm{~cm}$, but statistically insignificant. In the variant in which the subsurface irrigation is located at $40 \mathrm{~cm}$, the highest humidity was registered on the profile $40-60 \mathrm{~cm}(11.8 \%)$, noting a distinctly significant increase of $3.7 \%$, compared to the value on the profile $0-20 \mathrm{~cm}$.

In the panic phase (July 8) the soil humidity was also differentiated on the three soil profiles, depending on the depth of burial of the drip tubes. Thus, in the variant with subsurface irrigation located at a depth of $20 \mathrm{~cm}$ there were no statistically assured differences on the soil profile variants, compared to subsurface irrigation located at a depth of $40 \mathrm{~cm}$, where the humidity on soil profiles $20-40 \mathrm{~cm}$ and $40-60 \mathrm{~cm}$ recorded significant increases compared to humidity determinations from $0-20 \mathrm{~cm}$. Analyzing the soil humidity in dynamics, up to the waxy milk phase of sorghum beans (August 03), its increases on the soil profile up to $60 \mathrm{~cm}$ were highlighted, registering statistically assured differences compared to the humidity values in the profile of $0-20 \mathrm{~cm}$, for subsurface irrigation located at a depth $040 \mathrm{~cm}$.

Between the two variants of localized subsurface irrigation, the variant in which the irrigation network was buried in the soil at a depth of $40 \mathrm{~cm}$ was highlighted, where the water was better preserved in the soil, the differentiations being ensured statistically as significant and distinctly significant, during sorghum vegetation.

Table 1

Evolution in dynamics of soil humidity

\begin{tabular}{|c|c|c|c|c|c|c|c|c|}
\hline \multirow{2}{*}{$\begin{array}{c}\text { Depth of } \\
\text { subsurface drip } \\
\text { irrigation, } \mathrm{cm} \\
\end{array}$} & \multirow{2}{*}{$\begin{array}{c}\text { Soil } \\
\text { profile, } \\
\text { cm }\end{array}$} & \multicolumn{7}{|c|}{ Humidity on the soil profile, $\%$} \\
\hline & & July 01 & July 08 & July 15 & July 23 & $\begin{array}{c}\text { Aug. } \\
\mathbf{0 3}\end{array}$ & $\begin{array}{c}\text { Aug. } \\
17\end{array}$ & $\begin{array}{c}\text { Aug. } \\
\text { 30 }\end{array}$ \\
\hline \multirow{3}{*}{$a_{1}=20$} & $\begin{array}{c}b_{1}=0-20 \\
(\text { control) }\end{array}$ & 9.1 & 8.3 & 9.2 & 10.2 & 8.5 & 8.1 & 7.5 \\
\hline & $b_{2}=20-40$ & 10.0 & 8.9 & 9.4 & 11.3 & 8.8 & 8.6 & 8.4 \\
\hline & $b_{3}=40-60$ & 10.3 & 9.0 & 8.6 & 11.4 & 7.9 & 7.7 & 7.3 \\
\hline \multicolumn{2}{|c|}{ Average $a_{1}$ (control) } & 9.8 & 8.7 & 9.1 & 11.0 & 8.0 & 8.1 & 7.7 \\
\hline \multirow{3}{*}{$a_{2}=40$} & $\begin{array}{c}b_{1}=0-20 \\
(\text { control) }\end{array}$ & 8.1 & 7.9 & 7.8 & 8,8 & 8 & 7,5 & 7 \\
\hline & $b_{2}=20-40$ & $11 *$ & $9.8 *$ & $11.9 * * *$ & $12.4 * *$ & $10.1 *$ & 9.0 & 8.1 \\
\hline & $b_{3}=40-60$ & $11.8 * *$ & $10.2 *$ & $13.1 * * *$ & $13.4 * * *$ & $10.3 *$ & 9.3 & 8.3 \\
\hline \multicolumn{2}{|c|}{ Average $a_{2}$} & 10.3 & $9.3^{*}$ & $10.9 * *$ & $11.5 * *$ & $9.5^{*}$ & $8.6^{*}$ & 7.8 \\
\hline \multirow{3}{*}{$a_{1} b_{2}-a_{1} b_{1}$} & LSD 5\% & 2.6 & 1.9 & 1.7 & 1.8 & 1.6 & 2.4 & 1.5 \\
\hline & LSD $1 \%$ & 3.7 & 2.8 & 2.4 & 2.6 & 2.4 & 3.4 & 2.3 \\
\hline & LSD $0.1 \%$ & 5.6 & 4.1 & 3.7 & 3.9 & 3.6 & 5.2 & 3.4 \\
\hline \multirow{3}{*}{$a_{2}-a_{1}$} & LSD 5\% & 0.3 & 0.4 & 0.3 & 0.2 & 0.8 & 0.3 & 1.0 \\
\hline & LSD $1 \%$ & 0.7 & 1.0 & 0.7 & 0.5 & 1.9 & 0.7 & 2.4 \\
\hline & LSD $0.1 \%$ & 2.3 & 3.1 & 2.3 & 1.5 & 6.0 & 2.3 & 7.6 \\
\hline
\end{tabular}

In the milk wax phenophase of the beans, in the second variant of irrigation, located at a depth of $40 \mathrm{~cm}$, the soil humidity was higher on the profiles $20-40 \mathrm{~cm}$ and $40-60 \mathrm{~cm}(10 \%)$ compared to the first variant of irrigation (humidity located around $8 \%$ ). Towards the end of the growing season, the soil humidity in both irrigation variants did not exceed $8.5 \%$.

Results regarding the soil momentary water supply (Table 2). The calculation of the soil momentary water supply, depending on the burial depth of the localized irrigation network showed a statistically assured differentiation during the period of maximum water consumption of the sorghum plant and the period between the bellows phase of the panicle (the first decade of July) to the wax phase of the grain (the second decade of August) (Table 2). The best results were recorded in the variant with the irrigation network located at a depth of $40 \mathrm{~cm}\left(218.6-326.6 \mathrm{~m}^{3} \cdot \mathrm{ha}^{-1}\right)$, the differences compared to the burial variant at $20 \mathrm{~cm}$ being of $13.3-53 \mathrm{~m}^{3} \cdot \mathrm{ha}^{-1}$, distinctly statistically significant.

The analysis of the soil momentary water supply showed increases in its value on the soil profile 40-60 cm, compared to the soil profile $0-20 \mathrm{~cm}$, differentiations statistically ensured in the irrigation variant located at a depth of $40 \mathrm{~cm}$. In the variant with irrigation located at a depth of $20 \mathrm{~cm}$, the soil momentary water supply did not differ significantly on the soil profile. 
Evolution in dynamics of the soil momentary water supply

\begin{tabular}{|c|c|c|c|c|c|c|c|c|}
\hline \multirow{2}{*}{$\begin{array}{c}\text { Depth of } \\
\text { subsurface drip } \\
\text { irrigation, cm }\end{array}$} & \multirow{2}{*}{$\begin{array}{c}\text { Soil } \\
\text { profile, } \\
\text { cm }\end{array}$} & \multicolumn{7}{|c|}{ Humidity on the soil profile, \% } \\
\hline & & July 01 & July 08 & July 15 & July 23 & $\begin{array}{c}\text { Aug. } \\
\mathbf{0 3}\end{array}$ & $\begin{array}{c}\text { Aug. } \\
17\end{array}$ & $\begin{array}{c}\text { Aug. } \\
\text { 30 }\end{array}$ \\
\hline \multirow{3}{*}{$a_{1}=20$} & $\begin{array}{c}b_{1}=0-20 \\
\text { (control) }\end{array}$ & 251.2 & 229.1 & 253.9 & 281.5 & 234.6 & 223.6 & 207.0 \\
\hline & $b_{2}=20-40$ & 280.0 & 249.2 & 263.2 & 316.4 & 246.4 & 240.8 & 235.2 \\
\hline & $b_{3}=40-60$ & 292.5 & 255.6 & 244.2 & 323.8 & 224.4 & 218.7 & 207.3 \\
\hline \multicolumn{2}{|c|}{ Average $a_{1}$ (control) } & 9.8 & 274.6 & 244.6 & 253.8 & 307.2 & 235.1 & 227.7 \\
\hline \multirow{3}{*}{$a_{2}=40$} & $\begin{array}{l}b_{1}=0-20 \\
\text { (control) }\end{array}$ & 223 & 2 & 215.3 & 242.9 & 220. & 207.0 & 19 \\
\hline & $b_{2}=20-40$ & $308.0^{*}$ & $274.4^{*}$ & $333.2 * * *$ & $347.2 * *$ & 282.8 & 252.0 & 226.8 \\
\hline & $b_{3}=40-6$ & $335.1^{* *}$ & $289.7 * *$ & $372.0 * * *$ & $380.6 * * *$ & $292.5 * *$ & 264.1 & 235.7 \\
\hline \multicolumn{2}{|c|}{ Average $a_{2}$} & 10.3 & $288.9^{*}$ & $260.7 *$ & $306.8^{* *}$ & $326.6 * *$ & $265.4^{*}$ & $241.0^{*}$ \\
\hline \multirow{3}{*}{$a_{1} b_{2}-a_{1} b_{1}$} & LSD 5\% & 72.8 & 53.2 & 47.0 & 50.4 & 45.6 & 66.2 & 43.3 \\
\hline & LSD 1\% & 103.6 & 77.3 & 68.4 & 72.8 & 66.4 & 96.4 & 63.0 \\
\hline & LSD 0 & 156.8 & 116.0 & 102.6 & 109.2 & 99.6 & 144.5 & 94.5 \\
\hline \multirow{3}{*}{$a_{2}-a_{1}$} & LSD 5 & 8. & & 8.7 & 5. & 22.9 & 8.7 & 29.1 \\
\hline & & 19.6 & 27.0 & 19.8 & 14.0 & 52.4 & 19.8 & 66.6 \\
\hline & LSD $0.1 \%$ & 64.4 & 86.8 & 63.7 & 42.0 & 168.6 & 63.7 & 214.0 \\
\hline
\end{tabular}

Results on soil water reserve. On the profile $0-20 \mathrm{~cm}$, the soil water reserve, in the variant with irrigation lines buried at a depth of $20 \mathrm{~cm}$, had values around the average of $120 \mathrm{~m}^{3} \cdot \mathrm{ha}^{-1}$, being higher than the second irrigation variant. The water reserve on the profile $20-40 \mathrm{~cm}$, in the irrigation variant located at $40 \mathrm{~cm}$ depth, had considerably higher values than the first irrigation variant. The maximum was recorded during the phenophases of flowering and grain formation, with values exceeding $210 \mathrm{~m}^{3} \cdot \mathrm{ha}^{-1}$. The same trend is maintained on the soil profile $40-60 \mathrm{~cm}$, this time the values being much more significant. In the variant with irrigation lines buried at $40 \mathrm{~cm}$, in all phenophases that the plants went through, the soil water reserve had values on average of over $200 \mathrm{~m}^{3} \cdot \mathrm{ha}^{-1}$, which decreased towards the end of the vegetation period (Figure 2).

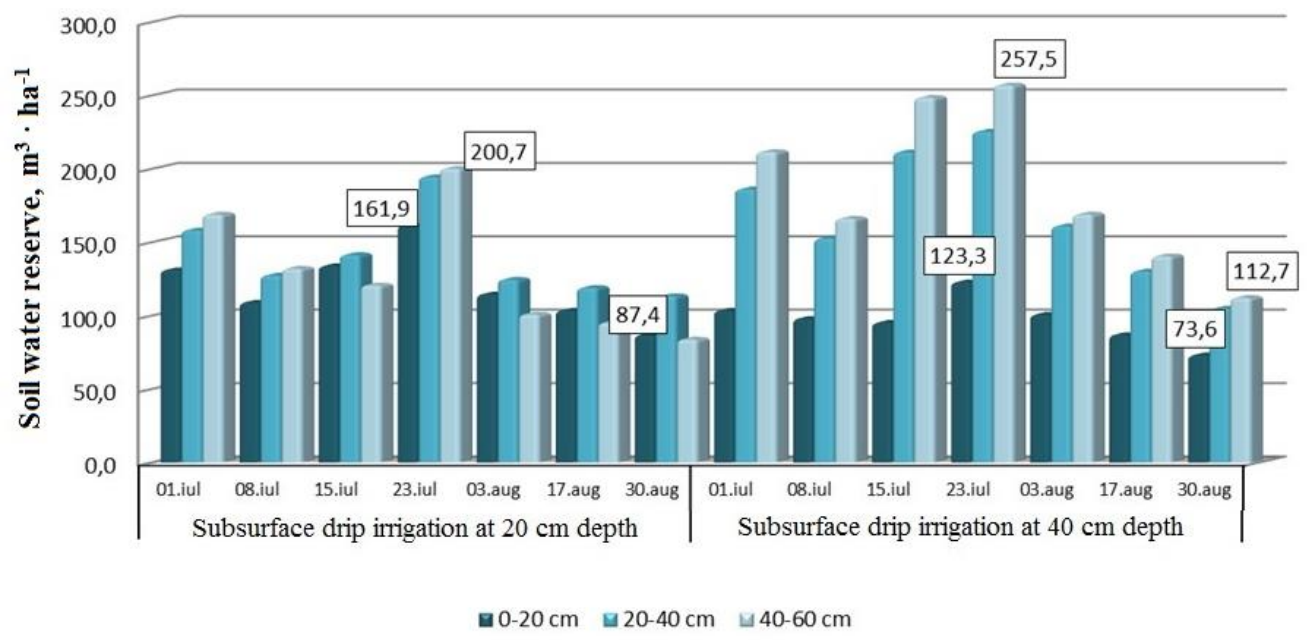

Fig. 2. Soil water reserve on the two irrigation variants

Results on soil water deficit. On the profile $0-20 \mathrm{~cm}$, the water deficit in the soil in the variant with irrigation lines buried at a depth of $40 \mathrm{~cm}$, had negative values during all phenophases, values between $-5.5 \mathrm{~m}^{3} \cdot \mathrm{ha}^{-1}$ (grain formation) and $-55.2 \mathrm{~m}^{3} \cdot \mathrm{ha}^{-1}$ (technical maturity of the grains), because a large part of the water that rises through the pores of the soil to the surface is quickly lost by evaporation, due to very high temperatures at the sand surface, which can reach $60^{\circ} \mathrm{C}$, and also due to soil loosening through crop maintenance work. The results obtained regarding the water deficit, calculated on the $20-40 \mathrm{~cm}$ profile, in the irrigation variant located at $40 \mathrm{~cm}$ depth, show that it had positive values, creating a 
favourable environment for the growth and development of sorghum plants, compared to the first irrigation variant, when there was a smaller water reserve in the soil. The range of values was between $22.4 \mathrm{~m}^{3} \cdot \mathrm{ha}^{-1}$ (panic occurrence) and $95.2 \mathrm{~m}^{3} \cdot \mathrm{ha}^{-1}$ (grain formation). Of course, the values decreased in August. On the soil profile $40-60 \mathrm{~cm}$ the same trend is maintained, this time the values being much more significant. In the variant with localized irrigation at $40 \mathrm{~cm}$, in all the phenophases that the plants went through, the water deficit in the soil had positive values, except for the end of August (Figure 3).

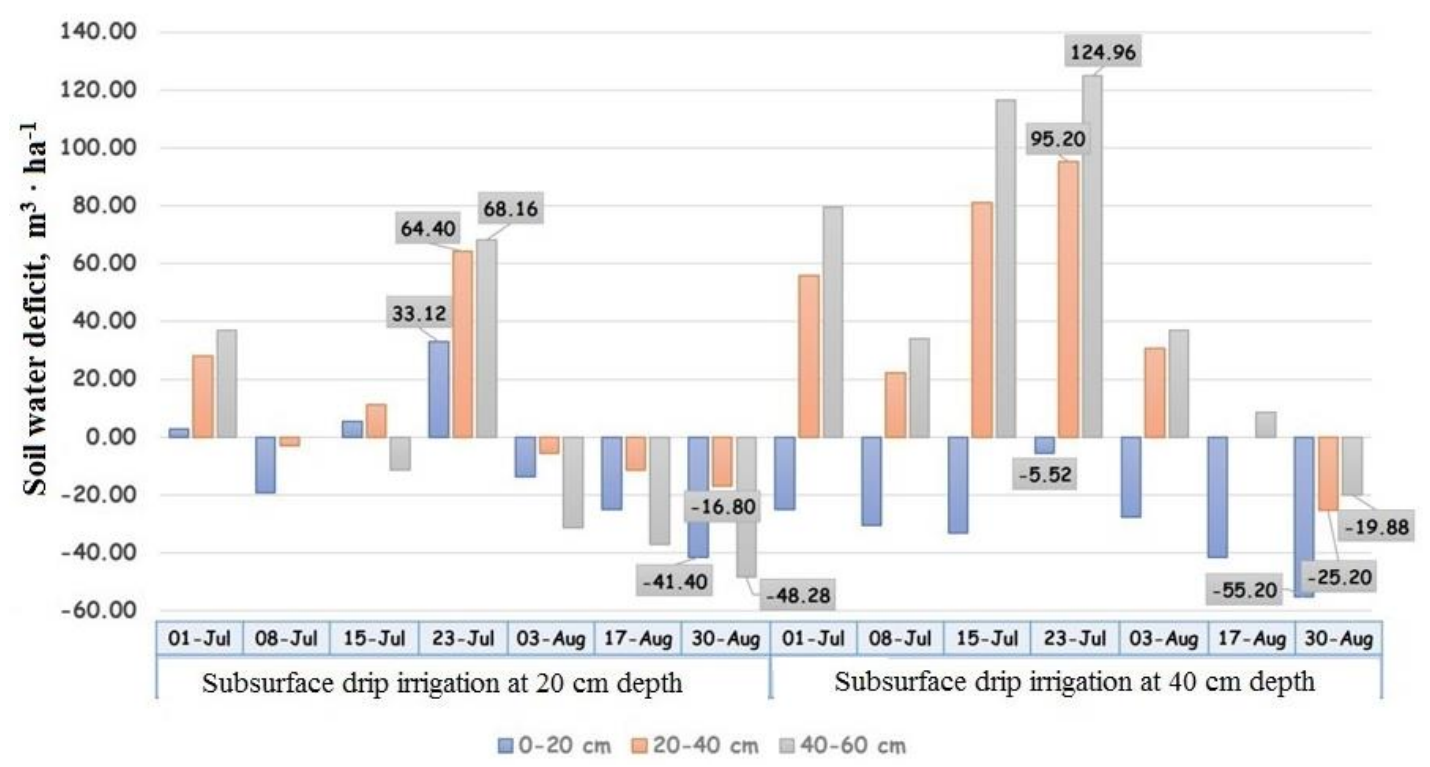

Fig. 3. Soil water deficit on the two irrigation variants

The biometrics determinations of the sorghum plant highlighted the plant height of 85.2-99.4 cm, stem diameter of 14.4-15.7 mm and the panicle length with values of 21-21.8 cm, highlighting with better results the variant of subsurface irrigation located at $40 \mathrm{~cm}$ in the soil (Table 3). In this irrigation variant, grain sorghum also performed better in terms of leaf surface index and grain weight.

Results of determinations on the growth and development

Table 3 of grain sorghum plants

\begin{tabular}{|c|c|c|c|c|c|c|}
\hline $\begin{array}{c}\text { Depth of } \\
\text { subsurface drip } \\
\text { irrigation, cm }\end{array}$ & $\begin{array}{c}\text { Plant size, } \\
\mathbf{c m}\end{array}$ & $\begin{array}{c}\text { Stem } \\
\text { diameter, } \\
\mathbf{m m}\end{array}$ & $\begin{array}{c}\text { Panicle } \\
\text { length, cm }\end{array}$ & $\begin{array}{c}\text { Leaf } \\
\text { surface } \\
\text { index }\end{array}$ & $\begin{array}{c}\text { Hectolitre } \\
\text { mass, } \\
\mathbf{k g} \cdot \mathbf{h} \mathbf{l}^{-\mathbf{1}}\end{array}$ & $\begin{array}{c}\text { Mass of } \\
\text { one } \\
\text { thousand } \\
\text { grains, } \mathbf{g}\end{array}$ \\
\hline 20 & 85.2 & 14.4 & 21.0 & 5.16 & 70 & 29 \\
\hline 40 & 99.4 & 15.7 & 21.8 & 6.35 & 73 & 27 \\
\hline
\end{tabular}

The obtained results highlighted a diurnal variation of the studied physiological processes in close connection with the changes of environmental factors during the day (especially light and temperature). Table 4 shows the average values of temperature and solar radiation active in photosynthesis, recorded directly in the experimental field, during the determinations. Both the temperature and the solar radiation showed very high values during the day the sorghum plants were subjected to the heat phenomenon.

Temperature and solar radiation in the phenophase

Table 4 of flowering-bean formation

\begin{tabular}{|c|c|c|c|}
\hline Diurnal variation & 9 a.m & 12 a.m. & 15 p.m. \\
\hline Active solar radiation in photosynthesis, $\mu \mathrm{mol} \cdot \mathrm{m}^{-2} \cdot \mathrm{s}^{-1}$ & 1150 & 1934 & 1957 \\
\hline Temperature, $^{\circ} \mathrm{C}$ & 29.3 & 35.6 & 36.1 \\
\hline Atmospheric pressure, $\mathrm{hPa}$ & 1008 & 1008 & 1007 \\
\hline
\end{tabular}


The diurnal variation of photosynthesis followed a unimodal curve with the maximum values recorded at 12 a.m. in both irrigation variants $\left(36.2-39.36 \mu \mathrm{mol} \mathrm{CO} 2 \cdot \mathrm{m}^{-2} \cdot \mathrm{s}^{-1}\right)$, and foliar perspiration (Table 5), varied during of the day, under the direct influence of the air temperature, of the closing/opening movements of the stomata, as well as of the irrigation variant. In dynamics, the perspiration presented the maximum values at $15 \mathrm{p} . \mathrm{m}$. (5.67-6.65 $\left.\mathrm{mmol} \mathrm{H}_{2} \mathrm{O} \cdot \mathrm{m}^{-2} \cdot \mathrm{s}^{-1}\right)$.

Table 5

\section{Physiology of the sorghum plant in the flowering} phase - bean formation (July 20)

\begin{tabular}{|c|c|c|c|c|c|}
\hline $\begin{array}{c}\text { Depth of } \\
\text { subsurface drip } \\
\text { irrigation, cm }\end{array}$ & $\begin{array}{l}\text { Physiological } \\
\text { processes }\end{array}$ & 9 a.m. & 12 a.m. & 15 p.m. & $\begin{array}{l}\text { Daily } \\
\text { average }\end{array}$ \\
\hline \multirow{4}{*}{20} & $\begin{array}{l}\text { Photosynthesis, } \\
\mu \mathrm{mol} \mathrm{CO} 2 \cdot \mathrm{m}^{-2} \cdot \mathrm{s}^{-1}\end{array}$ & 31.25 & 36.2 & 29.8 & 32.42 \\
\hline & $\begin{array}{l}\text { Foliar perspiration, } \\
\mathrm{mmol} \mathrm{H}_{2} \mathrm{O} \cdot \mathrm{m}^{-2} \cdot \mathrm{s}^{-1}\end{array}$ & 3.24 & 6.53 & 6.65 & 5.39 \\
\hline & $\begin{array}{l}\text { Chlorophyll content, } \\
\text { CCI units }\end{array}$ & 39.41 & 42.36 & 40.15 & 40.64 \\
\hline & $\begin{array}{c}\text { Stomach conductance, } \\
\mathrm{mol} \cdot \mathrm{m}^{-2} \cdot \mathrm{s}^{-1}\end{array}$ & 0.15 & 0.28 & 0.23 & 0.22 \\
\hline \multirow{4}{*}{40} & $\begin{array}{l}\text { Photosynthesis, } \\
\mu \mathrm{mol} \mathrm{CO}_{2} \cdot \mathrm{m}^{-2} \cdot \mathrm{s}^{-1}\end{array}$ & 35.2 & 39.36 & 34.42 & 36.33 \\
\hline & $\begin{array}{l}\text { Foliar perspiration, } \\
\mathrm{mmol} \mathrm{H}_{2} \mathrm{O} \cdot \mathrm{m}^{-2} \cdot \mathrm{s}^{-1}\end{array}$ & 2.21 & 4.83 & 5.67 & 4.24 \\
\hline & $\begin{array}{l}\text { Chlorophyll content, } \\
\text { CCI units }\end{array}$ & 47.24 & 54.23 & 42.2 & 47.89 \\
\hline & $\begin{array}{c}\text { Stomach conductance, } \\
\mathrm{mol} \cdot \mathrm{m}^{-2} \cdot \mathrm{s}^{-1}\end{array}$ & 0.09 & 0.19 & 0.2 & 0.16 \\
\hline
\end{tabular}

The chlorophyll content showed a diurnal variation, with values ranging from 39.41-42.36 CCI units, in the irrigation variant located at $20 \mathrm{~cm}$ depth and in the range of 42.2-54.23 CCI units, in the irrigation variant located at $40 \mathrm{~cm}$ depth, being positively correlated with the photosynthesis process.

Determinations on the amount of water and dry matter in the leaves (Table 6), performed in the phenophase of flowering-bean formation, showed values between $73.61 \%$ (subsurface irrigation located at $20 \mathrm{~cm}$ in the soil) and $74.09 \%$ (subsurface irrigation located at $40 \mathrm{~cm}$ in the soil). In terms of water bound from the leaves, the subsurface irrigation located at a depth of $40 \mathrm{~cm}$ was highlighted, where a significant part of the plant water was strongly bound at the cellular level, to cope with the thermohydric stress during the summer, this presenting the value of $6.21 \%$. The lower the water content, the higher the percentage of dry matter, so that it reached a maximum of $26.39 \%$ at subsurface irrigation located at $20 \mathrm{~cm}$.

\section{Water forms and dry matter in grain sorghum, depending on subsurface irrigation}

Table 6

\begin{tabular}{|c|c|c|c|c|}
\hline $\begin{array}{c}\text { Depth of } \\
\text { subsurface drip } \\
\text { irrigation, cm }\end{array}$ & $\begin{array}{c}\text { Dry matter, } \\
\text { \% }\end{array}$ & $\begin{array}{c}\text { Total water, } \\
\mathbf{\%}\end{array}$ & $\begin{array}{c}\text { Free water, } \\
\mathbf{\%}\end{array}$ & $\begin{array}{c}\text { Bound water, } \\
\text { \% }\end{array}$ \\
\hline 20 & 26.39 & 73.61 & 68.36 & 5.25 \\
\hline 40 & 25.91 & 74.09 & 67.88 & 6.21 \\
\hline
\end{tabular}

The analysis of the results obtained at sorghum highlighted a better use of subsurface irrigation with the location of drips at $40 \mathrm{~cm}$ in the soil, the level of grain sorghum production being $5758.3 \mathrm{~kg} \cdot \mathrm{ha}^{-1}$, with a difference of $1182.3 \mathrm{~kg} \cdot \mathrm{ha}^{-1}$, distinctly significant compared to irrigation located at $20 \mathrm{~cm}$ in the soil (Table 7). 
Yield results obtained at grain sorghum

\begin{tabular}{|c|c|c|c|c|}
\hline \multirow{2}{*}{$\begin{array}{l}\text { Depth of subsurface } \\
\text { drip irrigation, } \mathbf{c m}\end{array}$} & \multicolumn{2}{|c|}{ Grain Yield } & \multirow{2}{*}{$\begin{array}{l}\text { Difference, } \\
\mathrm{kg} \cdot \mathrm{ha}^{-1}\end{array}$} & \multirow{2}{*}{ Significance } \\
\hline & $\mathrm{kg} \cdot \mathrm{ha}^{-1}$ & $\%$ & & \\
\hline $20 \mathrm{~cm}$ & 4576 & 100 & Control & Control \\
\hline $40 \mathrm{~cm}$ & 5758.3 & 125.8 & 1182.3 & $* *$ \\
\hline & & $\begin{array}{r}\text { LSD } 5 \% \\
\text { LSD } 1 \% \\
\text { LSD } 0.1 \%\end{array}$ & $\begin{array}{r}476.7 \\
1100.8 \\
3502.9\end{array}$ & \\
\hline
\end{tabular}

\section{Conclusions}

1. The subsurface drip irrigation has been successfully exploited in grain sorghum cultivation.

2. The evolution in soil humidity dynamics during the development of sorghum plants has highlighted the advantages of burying the drip lines at a depth of $40 \mathrm{~cm}$.

3. Subsurface irrigation located at $40 \mathrm{~cm}$ depth generated a lower humidity deficit, only in the soil profile $0-20 \mathrm{~cm}$, compared to irrigation located at $20 \mathrm{~cm}$.

4. The biometric determinations highlighted a better development of sorghum plants in the variant of subsurface irrigation located at $40 \mathrm{~cm}$ in the soil.

5. The chlorophyll content of the plants showed a diurnal variation, having values in the range of 39.41-42.36 CCI units, in the irrigation variant located at $20 \mathrm{~cm}$ and in the range 42.2-54.23 CCI units in the subsurface irrigation variant located at $40 \mathrm{~cm}$, being positively correlated with the process of photosynthesis.

6. In terms of water bound from the leaves, subsurface irrigation located at a depth of $40 \mathrm{~cm}$ was highlighted, where some of the plant water was strongly bound at the cellular level to cope with the thermohydric stress during the summer.

7. The analysis of the results obtained in sorghum highlighted the better use of subsurface irrigation with the location of drip lines at $40 \mathrm{~cm}$. With this method, the water is distributed in the area of root development and ensures an optimal humidity in the soil for a longer period, with no losses, compared to the burial variant of the drip lines at $20 \mathrm{~cm}$, when a significant part of the water that rises in the soil layer to the surface, through the capillary ascent, is lost by evaporation.

\section{Acknowledgements}

This work was supported by a grant of the Romanian Ministry of Research and Innovation CCDI UEFISCDI, Project "Innovative technologies for irrigation of agricultural crops in arid, semiarid and subhumid-dry climate", project number PN-III-P1-1.2-PCCDI-2017-0254, contract no. 27PCCDI/2018 and project PN 191002 01- "Development of innovative technologies in smart farms" within the Program NUCLEU 2019 - 2022.

\section{References}

[1] Bora C., Popescu C.V. Rational use of irrigation in the central area of Oltenia (in Romanian). Alma Publishing House, Craiova, 2002.

[2] Murley C., Sharma S., Warren J., Arnall B., Raun W. Yield response of corn and grain sorghum to row offsets on subsurface drip laterals. Agricultural Water Management, 208, 2018, pp. 357-362.

[3] Isticioaia S., Trotuș E., Popa D., Leonte A., Vlăduț V., Voicea I., Ganea I., Matei Gh. The development of an innovative technology for sweet sorghum cultivation in the pedoclimatic conditions from the center of Moldova. ISB-INMA TEH International Symposium "Agricultural and Mechanical Engineering” 2019, Bucharest, pp. 203-210.

[4] Matei Gh. Study on yield features of sweet sorghum hybrids grown in south west of Romania. 16th International Multidisciplinary Scientific Geoconference (SGEM 2016) "Nano, Bio and Green technologies for a sustainable future" Conference Proceedings, Vol. I, 2016, Albena, Bulgaria, pp. 783-790.

[5] Matei Gh., Vlăduț V., Dodocioiu A. M., Toader M. Study regarding the optimization of grain sorghum cultivation technology. Scientific Papers-Series A-Agronomy, Vol. 63, Issue: 2, pp. 145 152. 
[6] Ungureanu N., Vlăduţ V., Voicu Gh. Water Scarcity and Wastewater Reuse in Crop Irrigation. Sustainability 2020, vol. 12 (21), 9055.

[7] Colaizzi P., Evett S., Howell T., Baumhardt R.L. Comparison of grain sorghum, soybean, and cotton production under SPRAY, LEPA and SDI. Proceedings of the " $21^{\text {st }}$ Annual Central Plains Irrigation Conference", February 24-25, Colby Kansas, 2002.

[8] Colaizzi P., Schneider A.D., Evett S., Howell T. Comparison of SDI, LEPA and spray irrigation performance for grain sorghum. Transactions of the American Society of Agricultural Engineers, 47, 2004

[9] Evett S., Marek G., Colaizzi P., Brauer D., O’Shaughnessy S. Corn and Sorghum ET, E, Yield, and CWP as Affected by Irrigation Application Method: SDI versus Mid-Elevation Spray Irrigation. Transactions of the ASABE, 62, 2019, pp. 1377-1393.

[10] Sakellariou-Makrantonaki M., Papanikolaou C. Biomass energy production by cultivating fiber sorghum in greece under intelligent irrigation methods. $2^{\text {nd }}$ WSEAS/IASME International Conference on RENEWABLE ENERGY SOURCES (RES'08) Corfu, Greece, October 26-28, 2019.

[11] Sakellariou-Makrantonaki M., Papalexis D., Nakos N., Dassios S. Potential And Water-Limited Growth And Productivity Of Fiber Sorghum In Central Greece Irrigated By Surface And Subsurface Drip Methods On A Rainy And A Dry Year. IASME/WSEAS International Conference on Energy \& Environmental Systems, Chalkida, Greece, May 8-10, 2006, pp. 49-54.

[12] Assefa Y., Staggenborg Scott, Vara P. V. Grain Sorghum Water Requirement and Responses to Drought Stress: A Review. Crop Management, 9, 2010.

[13] Academy of Agricultural and Forestry Sciences "Gheorghe Ionescu-Şişeşti”" Bucharest, 50 years of Research - Development at Research-Development Station for Plant Culture on Sands, Sitech Publishing House, Craiova, 2009, Romania.

[14] Dumitru M., Manea A., Ciobanu C., Dumitru S., Vrînceanu N., Rîşnoveanu I., Calciu I., Tănase V., Preda M., Mocanu V., Eftene M. Soil quality monitoring in Romania. Sitech Publishing House, Craiova, 2011. 